EÜFBED - Fen Bilimleri Enstitüsü Dergisi Cilt-Sayı: 8-1 Yıl: 2015 69-87

\title{
ANALYSIS OF HIP PROSTHESIS PRODUCTION WITH FORGING USING THE FINITE ELEMENT METHOD
}

\section{DÖVME İLE KALÇA PROTEZİ ÜRETIMININ SONLU ELEMANLAR YÖNTEMIYYLE İNCELENMESİ}

\author{
1Hojjat GHAHRAMANZADEH ASL, 2Sinan SEZEK, * Akgün \\ ALSARAN
}

${ }^{1}$ Atatürk University, Mechanical Engineering Department, 25240, Erzurum, Turkey

${ }^{2}$ Atattürk University, Vocational School of Aşkale, Erzurum, Turkey

Geliş Tarihi (Received): 09/01/2015 Kabul Tarihi (Accepted): 09/03/2015

\begin{abstract}
Hip prostheses used to fulfill injured or fractured limbs are made by machining, casting and plastic forming. Machining is the most commonly used one. However, there are many disadvantages such as high product cost in machining. Plastic forming methods provide more effective and durable implant production than machining. In this study, hip prosthesis with a complex geometry produced by forging were analyzed using the Finite Element Method (FEM). For this purpose, three-dimensional complex geometry was designed and then, FEM analyses were performed using MSC SIMUFACT 10 software. Factors affecting the production were defined as: temperature, friction coefficient and the pressing velocity. Stress distributions, temperature changes, die wears and punch forces applied to the die were examined. As a result of the study, the most suitable parameters were obtained as $500^{\circ} \mathrm{C}, 0.05$ coefficient of friction and $2 \mathrm{~mm} / \mathrm{s}$ die velocity. Also, the obtained FEM results were examined by regression analyses.
\end{abstract}

Keywords: Hip prosthesis, Forging, Ti6Al4V, Finite Element Method, Regression analysis

\section{ÖZET}

Yaralı veya kırık uzuvlarn işlemini yerine getirmek için kullanılan kalça protezleri döküm, plastik şekillendirme ve talaşlı imalat yöntemleri ile üretlmektedir. $\mathrm{Bu}$ konuda talaşlı imalat en yaygın olarak kullanılan yöntemdir. Ancak, talaşlı imalat yönteminin yüksek ürün maliyeti gibi bir çok dezavantajları vardır. Plastik şekillendirme yöntemleri daha etkin ve dayanıklı implant üretimi sağlar. Bu çalışmada, karmaşık geometriye sahip kalça protezinin dövme ile üretimi Sonlu Elemanlar Yöntemi (FEM) kullanılarak analiz edilmiştir. Bu amaçla, kalça protezin üç boyutlu modeli 
Hojjat and Diğerleri

tasarlanmıştır ve daha sonra, FEM analizler MSC SIMUFACT 10 yazılımı kullanılarak yapılmıştır. Sıcaklık, sürtünme katsayısı ve presleme hızı üretimi etkileyen faktörler olarak tanımlanmıştır. Gerilme dağılımları, sıcaklık değişiklikleri ve kalıba uygulanacak kuvvet miktarı değerleri incelenmiştir. Çalışmanın sonucunda, en uygun parametreler $500^{\circ} \mathrm{C}$ sıcaklık, $2 \mathrm{~mm} / \mathrm{s}$ presleme hızı ve 0.05 sürtünme katsayısı olarak elde edilmiştir. Aynı zamanda, elde edilen FEM sonuçları regresyon analizi ile incelenmiştir.

Anahtar Kelimeler: Kalça Protezi, Dövme, Ti6Al4V, Sonlu elemanlar Yöntemi, Regresyon analizi

\section{INTRODUCTION}

Hip prostheses are generally made of materials such as $\mathrm{Ti}$ alloy, Co alloy and stainless steel. Forging and plastic forming methods are utilized for production. Hip prosthesis design steps depend on the manufacturing process and implant materials. Particularly, for production of Ti alloy based implants by plastic deformation, determination of material behavior during deformation and its effects on the die are required. Due to its high production and material cost identifying potential futureFfig problems before making the die is imperative. Another important issue that should be considered in designing of die is the production time. Application of FEM before manufacturing could decrease both the processing time and the cost. Özkor (2011) showed that using FEM could decrease the design expense by $50 \%$, scrap materials $15 \%$ and material lost $10-30 \%$.

Important factors in forging are temperature, friction coefficient and die velocity. If these effective factors are determined correctly for $\mathrm{Ti}$ alloy forging, most of the difficulties in hip manufacturing could be eliminated. Therefore, before the start of production, for detecting problems that are likely to occur, simulation of the design and manufacturing process by computer simulation have got many advantageous. Due to the repeat-fail method that is usually used in die designing, equipment selection and process condition choices; hot forging is considered to be one of most expensive and time consuming processes. In some of the processes, for material control, dimensions and main structural inspection of the part that is to be forged can take a long time. (Caporalli et al.,1998) conducted research into the time saving abilities in die, part and raw materials designing. (Tetsui et al.,2005) forged Ti42Al5Mn alloy for analyzing effects of production temperature. A press of 700 tones was

EÜFBED - Fen Bilimleri Enstitüsü Dergisi Cilt-Say1: 8-1 Yıl: 2015 69-87 
Analysis of Hip Prosthesis Production with Forging Using used for this forging and for press velocity $10-20 \mathrm{~mm} / \mathrm{s}$ was chosen. Firstly, for a period of time the die was placed into the oven with a higher temperature than that of which the experiments took place and then was used in the process. After-wards, for determining the actual die temperature in forging process they studied temperature distribution in the die. During hot forming, re-crystallization is common. In forging, the investigation of strain and temperature effects based on material flow is sometimes possible. During hot forming, mechanical behavior of materials could be researched. (Skubisz et al., 2006) studied hot and semi-hot forging processes of MgAlZn alloy in a closed die. The part that they forged had a complex geometry which they have worked on with various temperatures. Essential force for pressing is decreased. This was shown by increasing the temperature. (Kim et al., 2005) have investigated die stress in the forging process, die temperature, and the effect of material flow on die wear. These values are at a maximum in the die. They concluded that by increasing the temperature, in the sharp corners, edge stress and temperature were higher than in other areas of the die. They also showed that increasing the temperature and material flow made increased die wear. During the forging process, friction is important factor and a lower friction status is desired. (Saiki et al.,2006) utilized oil in hot and cold deformation and measured the thickness by using the ultrasonic reflection method. (Wilson et al., 2004) Surface roughness and lubrication that affect friction coefficient are extremely important in forging and they are considered to be a considerable problem in the process i.e. they change place-time curve. Effects of friction coefficient in the forging could be investigated using FEM. Hallstrom (2000) showed that by increasing temperature and decreasing friction coefficient, the value of stress in the material decreased. (Ou and Balendra, 1998) have investigated the effects of friction coefficients in the turbine blade production process using ABAQUS. As a result, they have proved important effects of friction coefficient during the forging process. Friction has an important role in determining the die life expectancy and optimization of the cost. Due to this, the estimating of die wear is necessary. Wear particularly is one of the most important factors in die failure. (Behrens and Schaefer, 2005) developed a FEM model for estimating wear in the die. They have also used the ARCHARD model for calculating wear in the die. They compared results after 200 cycles theoretically and experimentally

EÜFBED - Fen Bilimleri Enstitüsü Dergisi Cilt-Say1: 8-1 Yıl: 2015 69-87 
Hojjat and Diğerleri

obtained die wear amounts and determined the optimum die wear ratio. Using the forging process typically needs to be carried out in multi-steps. Specifying step numbers is important from the view of obtaining the final shape. (Huang, 2005), have carried out the forging process on Ti47Al2Cr1Nb alloy in $1100-1150^{\circ} \mathrm{C}$ with plastic deformation rate $0.05-0.12$. They have forged the alloy in one step and also two steps, and attained the best results from two step forging. In this study, analysis of the hip prosthesis forging processes by using FEM is the prime target. As shown in the literature, theoretical analyses of hip prostheses using complex geometry have not been studied. For attaining this goal, the model of complex hip prosthesis using SolidWorks 2012 software has been created. In next step, preformation and last deformation die designed. FEM analyzing have utilized by MSC SIMUFACT 10 software. In order to confirmation of the experiment's values, a regression analysis was applied on the dependents variables (Stress distribution, temperature change, dies wear and punch force).

\section{METHODS}

Tool Steel and Ti6Al4V are die and work-piece materials, respectively. Mechanical and thermal properties of these materials are shown in Table 1.

Table 1. Properties of Ti6Al4V and Tool Steel.

\begin{tabular}{|c|c|c|}
\hline Materials properties & Ti6Al4V & Tool Steel \\
\hline Modulus of elasticity (GPa) & 113.8 & 207 \\
\hline Poisson's ratio & 0.342 & 0.3 \\
\hline Density $\left(\mathrm{kg} / \mathrm{m}^{3}\right)$ & 4430 & 7850 \\
\hline Thermal conductivity Watt/(m*k) & 6.7 & 32.9 \\
\hline $\begin{array}{c}\text { Specific heat capacity } \\
\text { Joule } /\left(\mathrm{kg}^{*} \mathrm{k}\right)\end{array}$ & 526.3 & 464 \\
\hline
\end{tabular}

At the beginning, 3D models and the die were designed by using SolidWorks software (Fig.1) and then, 3D models transferred to MSC SIMUFAC V.10 software for FEM analysis.

EÜFBED - Fen Bilimleri Enstitüsü Dergisi Cilt-Say1: 8-1 Yıl: 2015 69-87 
Analysis of Hip Prosthesis Production with Forging Using

Fig. 1. Designed 3D model of the hip prosthesis

Preforming and last forming operation sequences were determined for the production of hip prosthesis. For analyses of preforming process Finite Volume (FV) and for last forming Finite Element Method (FEM) were used. During the process simulation, parameters that affect the production process are shown in Table 2.

Table 2. Production parameters.

\begin{tabular}{|c|c|c|c|c|c|c|c|}
\hline $\begin{array}{c}\text { Producing } \\
\text { stage }\end{array}$ & \multicolumn{2}{|c|}{ Punch Rate (mm/s) } & \multicolumn{2}{|c|}{$\begin{array}{c}\text { Temperature } \\
{ }^{\circ} \mathrm{C}\end{array}$} & \multicolumn{2}{|c|}{$\begin{array}{c}\text { Friction } \\
\text { Coefficient }\end{array}$} \\
\hline preforming & \multicolumn{2}{|c|}{2} & \multicolumn{2}{|c|}{300} & \multicolumn{2}{|c|}{0.05} \\
\hline Last forming & 2 & 6 & 10 & 300 & 500 & 0.05 & 0.07 \\
\hline
\end{tabular}

For preforming process, die and work piece were arranged in MSC SIMUFACT software environment. At this stage, the hydraulic press type was selected for forging and the load was applied from upper die. After introducing mesh properties, the pressing process was performed (Fig. 2).

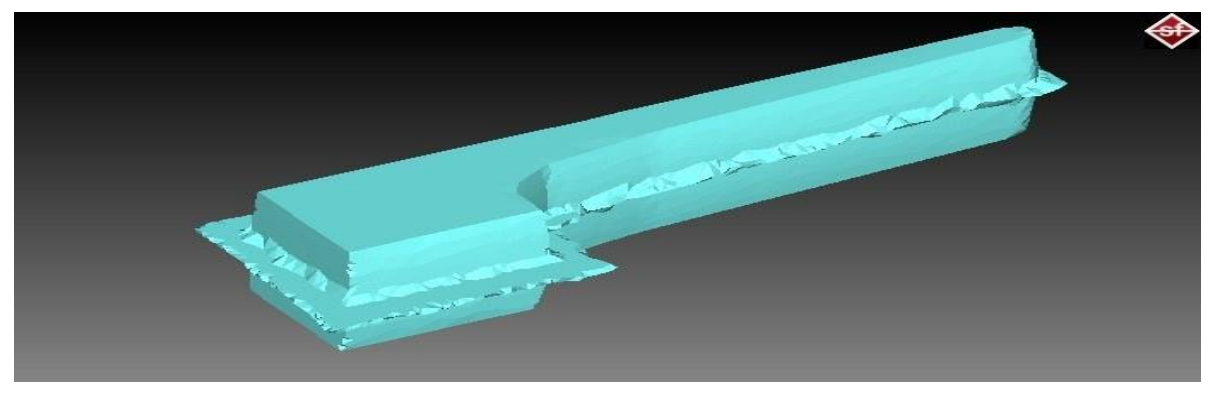

EÜFBED - Fen Bilimleri Enstitüsü Dergisi Cilt-Say1: 8-1 Yıl: 2015 69-87 

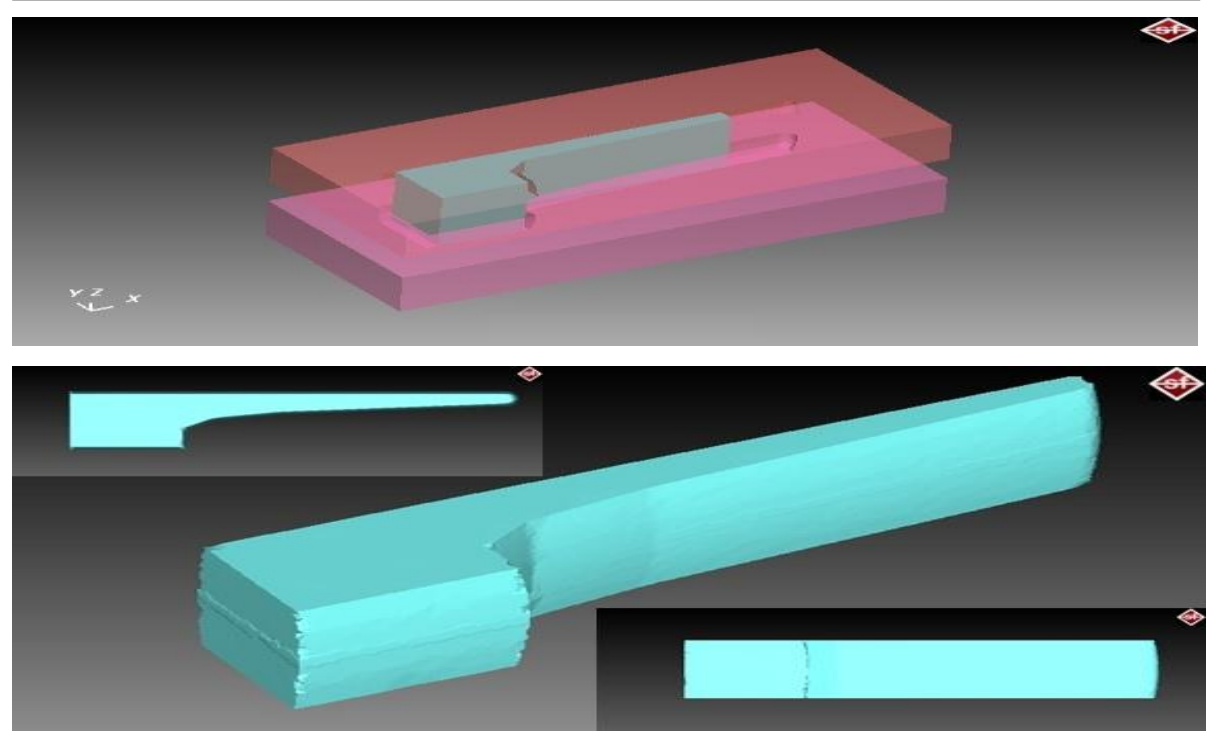

Fig. 2. Preforming die arrangement and obtained work-piece.

The last forming die was arranged using MSC SIMUFACT software. Resulted properties during the preforming step i.e. residual stress, dislocations, material defects and grain structures without any change was transferred to the last forming step, which is one of the most important advantages of the software (Fig.3).

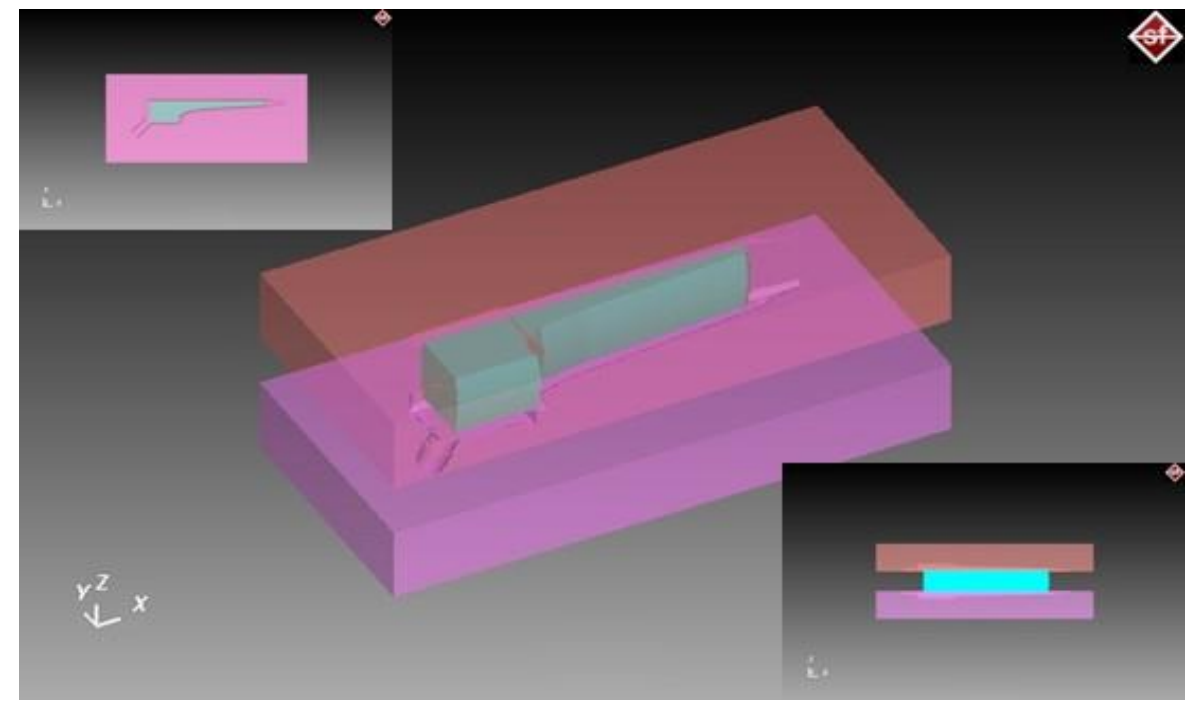

Fig. 3. Last forming die arrangement.

EÜFBED - Fen Bilimleri Enstitüsü Dergisi Cilt-Sayı: 8-1 Yıl: 2015 69-87 
Analysis of Hip Prosthesis Production with Forging Using In all models for FEM analysis, the PATRAN TETRA mesh structure was selected. This type of mesh has a triangular structure. After introducing this type of mesh property, in each analysis step, during the remeshing process the edge angles would change, so the software automatically adds extra nodes to the middle of the extended edge to regulate the mesh. The mesh structure of the work piece and die in last forming is shown in Fig.4.
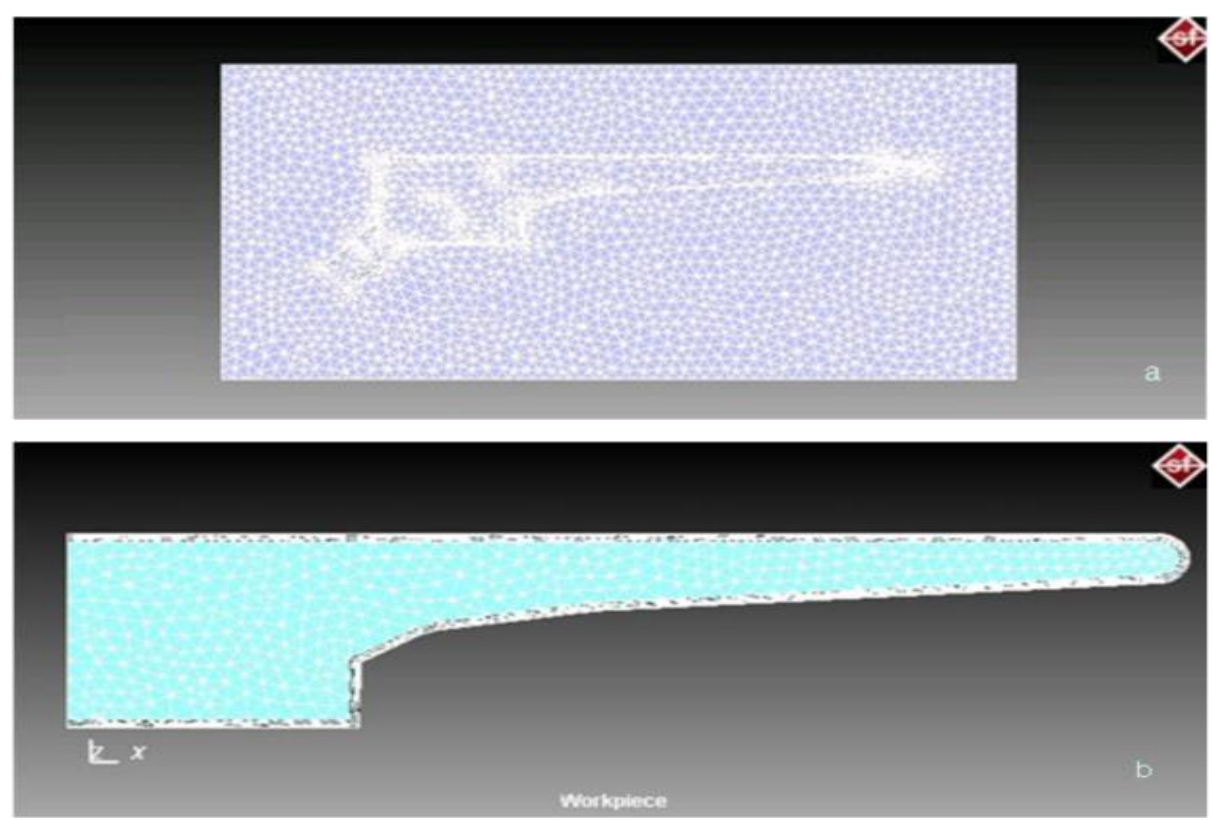

Fig. 4. Mesh structure in last forming (a) Die, (b) Work piece.

The regulating process will be executed in the pre-introduced area which will be determined by the user. In this study, FEM analyses were accomplished in 65 steps and remesahing were carried out in each step. Obtained work pieces from the last forming stage is shown in Fig.5.

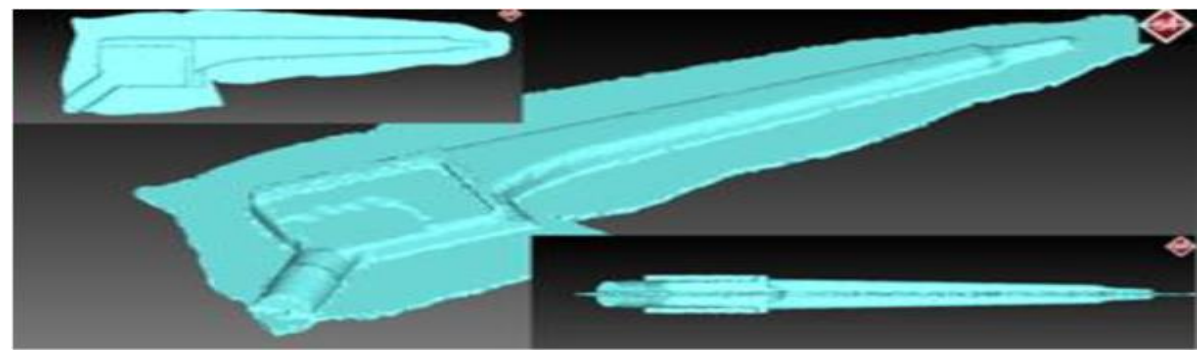

EÜFBED - Fen Bilimleri Enstitüsü Dergisi Cilt-Say1: 8-1 Yıl: 2015 69-87 
Hojjat and Diğerleri

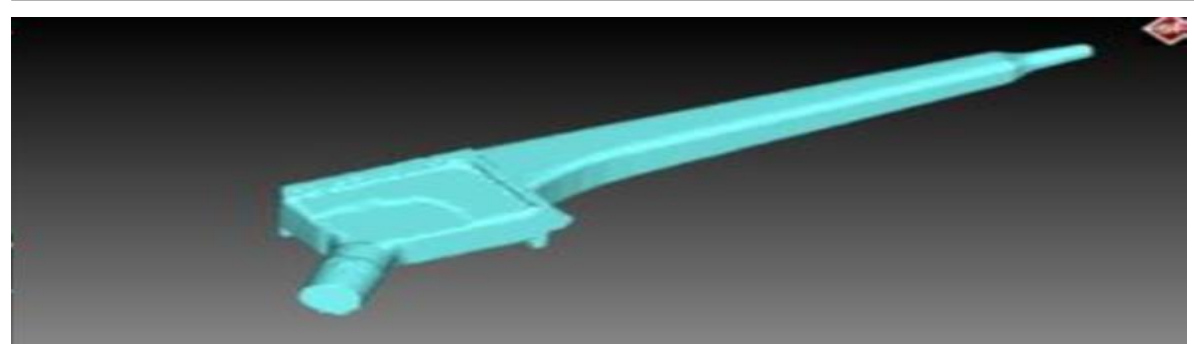

Fig. 5. Obtained hip prosthesis work piece from last forming stage.

At the end of the study carried out step-wise regression analysis on the results, with SPSS software and how effective factors are studied.

\section{RESULTS and DISCUSSION}

FEM can be used to forecast featuring problems and is highly effective for eliminating possible outgoing mistakes and in saving time, work and materials. Due to the short analysis time in FV, it has been used for preforming analyses. The work piece obtained during the preforming step was transferred to the last forming step with all the resulting parameters. It has shown that analysis of die and workpieces leads to a high material flow performance and the existence of material flow in every corner is preferable (Fig.5). As shown in Fig.5, in the flow rate of $95 \%$, there is nominal flow in the fins and corners where material flow is difficult. At the beginning of preforming, process temperature was $300^{\circ} \mathrm{C}$, and then it raised to $420^{\circ} \mathrm{C}$ when the process finished. In the pressing process with an inadequate die design, not only the material flow is not stable, but also in some areas material flow is too high or too low which will lead to a decrease in work piece formability.

Additionally, in this study, high material flow rate in the ends of hip prosthesis and low material flow in the blades were expected for the prosthesis because of its geometrical complexity. In addition, formability of work pieces depends vastly on not only the last forming die design, but also the preforming die and work piece design. Problems are minimized and the model forming process was completed.

It is imperative to specify the punch force in the forging process. In case of an incorrect punch force in the forging, time increases and the final shape will not be as desired. A higher punch force causes

EÜFBED - Fen Bilimleri Enstitüsü Dergisi Cilt-Say1: 8-1 Yıl: 2015 69-87 
Analysis of Hip Prosthesis Production with Forging Using deformation, hardening and a higher material flow rate, which lead to an unsatisfactory shape forming in the corners.

As seen in Fig.6, punch force changes with temperature. Analyses of this study have shown that for $10 \mathrm{~mm} / \mathrm{s}$ punch rate, $300^{\circ} \mathrm{C}$ and $500^{\circ} \mathrm{C}$ work-piece temperatures required forces of $6651 \mathrm{kN}$ and $6511 \mathrm{kN}$ respectively. Additionally, it has been shown that by increasing the punch rate, the required force will be increased and the optimum rate was found to $2 \mathrm{~mm} / \mathrm{s}$. In the optimum rate the required punch forces in the $300^{\circ} \mathrm{C}$ and $500^{\circ} \mathrm{C}$ temperature are $6350 \mathrm{kN}$ and $5642 \mathrm{kN}$. As expected, the force decreases by increasing the work-piece temperature. (Hu and Dean, 2001) studied Ti6Al4V forging processes and showed that; applied force will be increased by increasing the stroke. In the same study, it has been shown that the required force for forging decreased with increasing the temperature. (Ou and Balendra, 1998) and (Doege et al., 2004) showed that at the same temperature and various friction coefficients, punch force increased by increasing the friction coefficient.

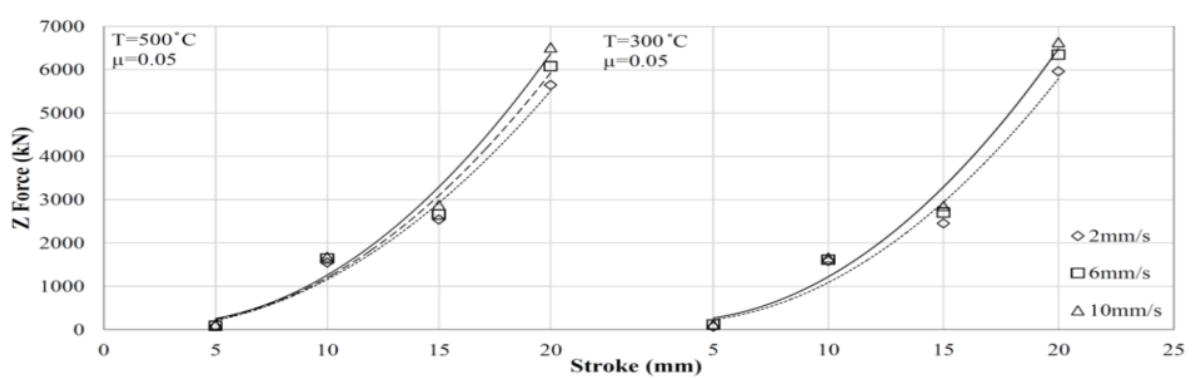

(a)

(b)

Fig. 6. Punch force values in $\mathrm{Z}$ direction (a) $\mathrm{T}=300^{\circ} \mathrm{C}$ and $\mu=0.05$, (b) $\mathrm{T}=500^{\circ} \mathrm{C}$ and $\mu 0.05$.

Regression analysis of pressing velocity, temperature and friction coefficient on punch force showed that there were significant effects on dependent variable (Table 3). Pressing velocity and friction coefficient had a positive effect on punch force respectively, while temperature had a negative effect. Adjusted $\mathrm{R}$ square of the regression analysis showed a high justification of the model $\left(\bar{R}^{2}=0.932\right)$. The results achieved by this analysis confirmed as discussed above.

EÜFBED - Fen Bilimleri Enstitüsü Dergisi Cilt-Say1: 8-1 Yıl: 2015 69-87 
Hojjat and Diğerleri

Table 3. Regression analysis of pressing velocity, temperature and friction coefficient on punch force

\begin{tabular}{|c|c|c|c|c|c|}
\hline \multirow{2}{*}{ Model } & \multicolumn{2}{|c|}{$\begin{array}{c}\text { Unstandardized } \\
\text { Coefficients }\end{array}$} & $\begin{array}{c}\text { Standardized } \\
\text { Coefficients }\end{array}$ & $\mathrm{t}$ & \multirow{2}{*}{ Sig. } \\
\cline { 2 - 5 } & $\mathrm{B}$ & Std. Error & Beta & & \\
\hline Pressing Velocity & 450.037 & 46.666 & .891 & 9.644 & .000 \\
\hline $\begin{array}{c}\text { Friction } \\
\text { Coefficient }\end{array}$ & 180.735 & 76.205 & .219 & 2.372 & .045 \\
\hline Temperature & -248.662 & 76.205 & -.301 & -3.263 & .011 \\
\hline
\end{tabular}

During the examination of stress distribution, it is apparent that stress distribution in material is uniform. There is no higher stress in any area; therefore there are no obstacles to the material flow in the forming process. Stress values in the hip prosthesis body are between $350 \mathrm{MPa}$ and $450 \mathrm{MPa}$ and between $550 \mathrm{MPa}$ and $700 \mathrm{MPa}$ in the corners and the sharp edged corners (Fig.7).

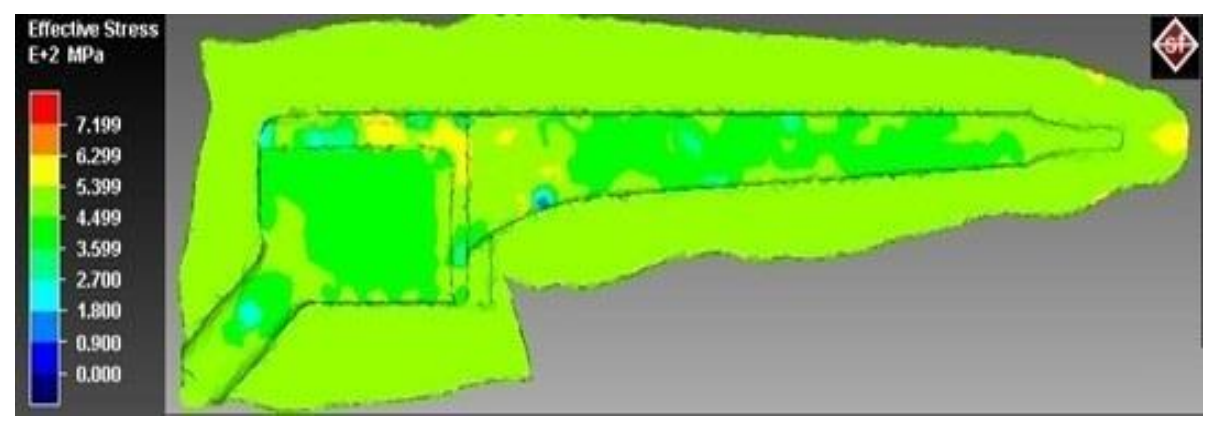

Fig. 7. Stress distribution on the work-piece,

Applied forming force caused increased plastic deformation energy along with temperature. Ti6Al4V alloys phase structure changes at $980^{\circ} \mathrm{C}$. For that reason, $500^{\circ} \mathrm{C}$ was chosen as an initial forging temperature to prevent the phase change in the alloy.

EÜFBED - Fen Bilimleri Enstitüsü Dergisi Cilt-Sayı: 8-1 Yıl: 2015 69-87 
Analysis of Hip Prosthesis Production with Forging Using

As shown in Fig.8, maximum stress at $500^{\circ} \mathrm{C}$ in the forging process is equal to $740 \mathrm{MPa}$. The minimum final stress is $670 \mathrm{MPa}$, which was obtained at $2 \mathrm{~mm} / \mathrm{s}$ punch rate. The maximum stress in case of keeping parameters is constant and only by changing friction coefficient obtained to $750 \mathrm{MPa}$. By increasing friction coefficient from 0.05 to 0.07 at $500^{\circ} \mathrm{C}$, the stress increased approximately $5 \%$. As shown in Fig.7, stress values are at their highest in the hip prosthesis corners and blades. Concentration of stress in the blades and corners is the reason of this phenomenon. (Garat et al., 2004) obtains identical results as this study showed the concentration of stress in the corners. (Feng and Luo, 2000) showed that stress increased during the forging process and also showed this by the moving forward of the die. In another study, (Lee and Lin, 1998) showed that by increasing the initial temperature, the stress values decreased; and our study proved this result.

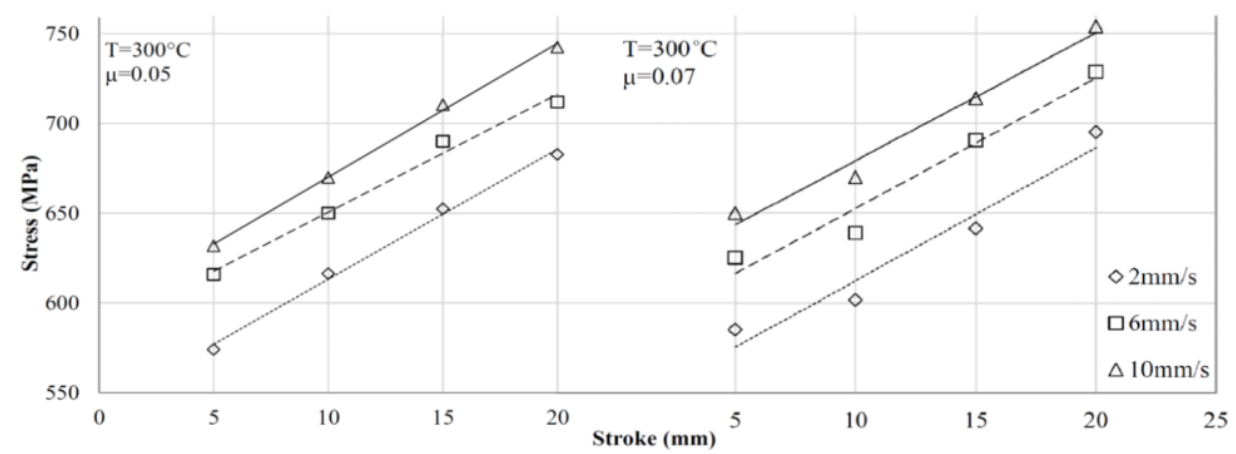

(a)

(b)

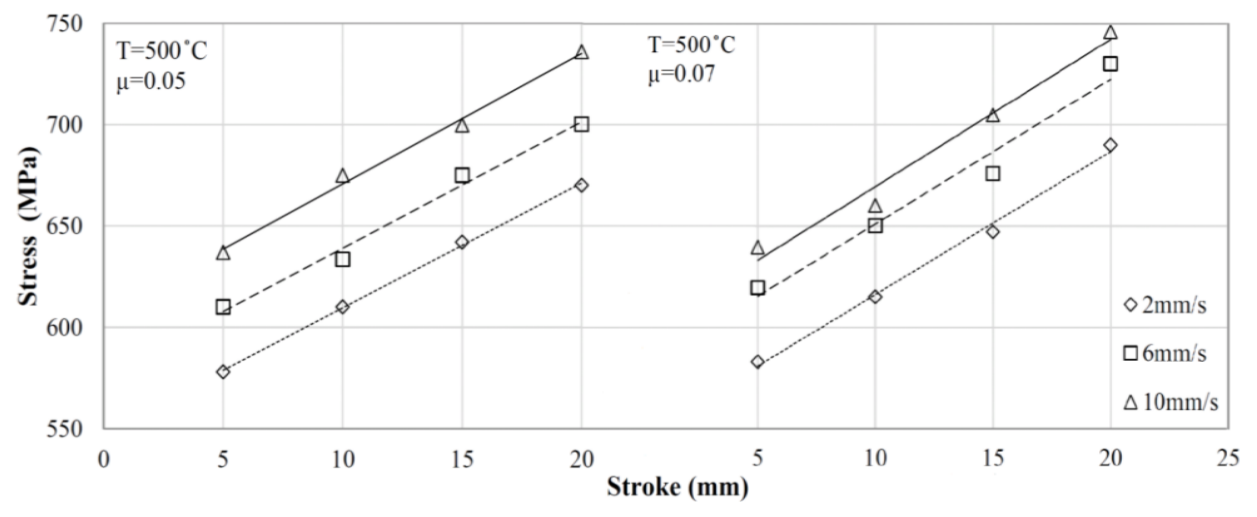

(c)

(d)

EÜFBED - Fen Bilimleri Enstitüsü Dergisi Cilt-Sayı: 8-1 Yıl: 2015 69-87 
Hojjat and Diğerleri

Fig. 8. Stress values curve (a) $\mathrm{T}=300^{\circ} \mathrm{C}$ and $\mu=0.05$, (b) $\mathrm{T}=300^{\circ} \mathrm{C}$ and $\mu=0.07$, (c) $\mathrm{T}=500^{\circ} \mathrm{C}$ and $\mu=0.05$, (d) $\mathrm{T}=500^{\circ} \mathrm{C}$ and $\mu=0.07$.

Regression analysis of pressing velocity, temperature and friction coefficient on stress showed that there are significant effects on dependent variable (Table 4). Pressing velocity and friction coefficient had a positive effect on stress respectively, while temperature had a negative effect. Adjusted $\mathrm{R}$ square of the regression analysis showed a high justification of the model $\left(\bar{R}^{2}=0.979\right)$. The results achieved by this analysis confirmed as discussed above.

Table 4. Regression analysis of pressing velocity, temperature and friction coefficient on stress

\begin{tabular}{|c|c|c|c|c|c|}
\hline \multirow{2}{*}{ Model } & \multicolumn{2}{|c|}{$\begin{array}{c}\text { Unstandardized } \\
\text { Coefficients }\end{array}$} & $\begin{array}{c}\text { Standardize } \\
\mathrm{d} \\
\text { Coefficients }\end{array}$ & $\mathrm{t}$ & \multirow{2}{*}{ Sig. } \\
\cline { 2 - 5 } & $\mathrm{B}$ & $\begin{array}{c}\text { Std. } \\
\text { Error }\end{array}$ & Beta & & \\
\hline Pressing Velocity & 30.049 & 1.645 & .928 & 18.264 & .000 \\
\hline $\begin{array}{c}\text { Friction } \\
\text { Coefficient }\end{array}$ & 16.695 & 2.687 & .316 & 6.214 & .000 \\
\hline Temperature & -7.138 & 2.687 & -.135 & -2.657 & .029 \\
\hline
\end{tabular}

The forging process was also modeled to obtain the most appropriate forging temperature at low temperature. Temperature change in cold forging experiments within $20^{\circ} \mathrm{C}$ ambient temperature is between $200^{\circ} \mathrm{C}$ and $400^{\circ} \mathrm{C}$. The last forging analysis was carried out at $300^{\circ} \mathrm{C}$ and $500^{\circ} \mathrm{C}$. $560^{\circ} \mathrm{C}$ was found to be the maximum temperature for the forging at $300^{\circ} \mathrm{C}$ with different punch rates. Temperature increase in forging that was processed in $300^{\circ} \mathrm{C}$ is equal to $80 \%$ of the initial temperature. The most suitable forging temperature is obtained at the $2 \mathrm{~mm} / \mathrm{s}$ punch rate. Temperature values for this punch rate and for 0.05 and 0.07 friction coefficients are between $370^{\circ} \mathrm{C}$ and $380^{\circ} \mathrm{C}$, respectively. Data from forging at

EÜFBED - Fen Bilimleri Enstitüsü Dergisi Cilt-Sayı: 8-1 Yıl: 2015 69-87 
Analysis of Hip Prosthesis Production with Forging Using $500^{\circ} \mathrm{C}$ with different friction coefficients are shown as curves in Fig.9,c,d. It is obvious that increasing plastic deformation energy is accompanied with a drop in temperature. In $500^{\circ} \mathrm{C}$ for 0.05 and 0.07 friction coefficients, an increment of $40 \%$ at temperatures was seen. For a fixed initial temperature, the change in the temperature steps up by increasing the punch rate. Constantly, for $2 \mathrm{~mm} / \mathrm{s}$ punch rate, the temperature change is at minimum (Campatelli and Scippa, 2012).

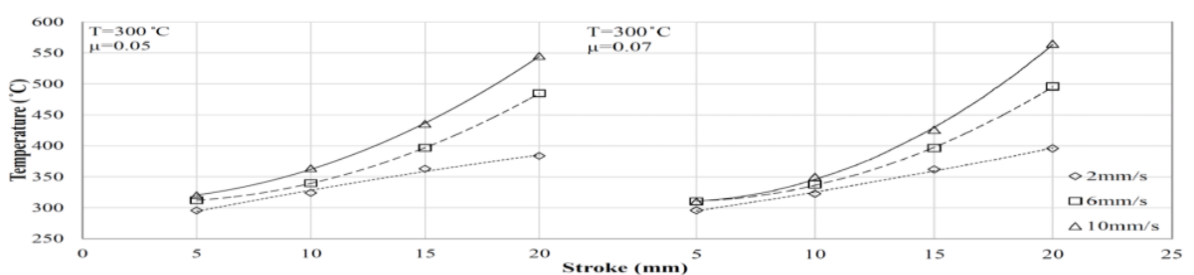

(a)

(b)

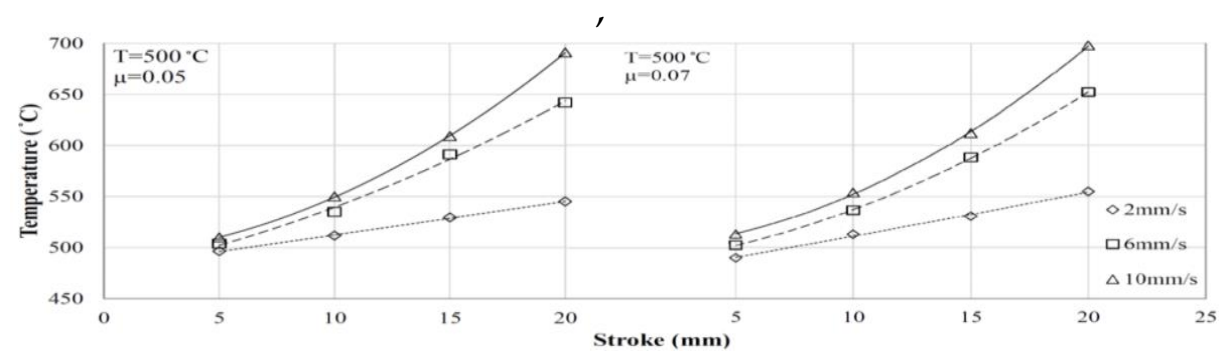

(c)

(d)

Fig. 9. Temperature change curves (a) $\mathrm{T}=300^{\circ} \mathrm{C}$ and $\mu=0.05$, (b) $\mathrm{T}=300^{\circ} \mathrm{C}$ and $\mu=0.07$ (c) $\mathrm{T}=500^{\circ} \mathrm{C}$ and $\mu=0.05$, (d) $\mathrm{T}=500^{\circ} \mathrm{C}$ and $\mu=0.07$.

Temperature change in the corners, edges and core of hip prosthesis are higher than the surface (Fig.10). (Kim et al., 2005) have observed high temperature in the sharp edges and corners. The temperature increased as expected by raise of the punch rate, friction coefficient and stroke. (Hallstrom, 2000) showed that the raising of the initial temperature leads to reduction of stress. (Likewise $\mathrm{Hu}$ et al., 1999) have utilized a forging process for producing turbine blades. In their study, they proved that the internal temperature was higher than the temperature in areas. As seen in the curves, the highest temperature value is seen at analyses with high punch rates.

EÜFBED - Fen Bilimleri Enstitüsü Dergisi Cilt-Say1: 8-1 Yıl: 2015 69-87 
Hojjat and Diğerleri

Increasing the punch rate, friction coefficient and stroke caused an increased temperature.

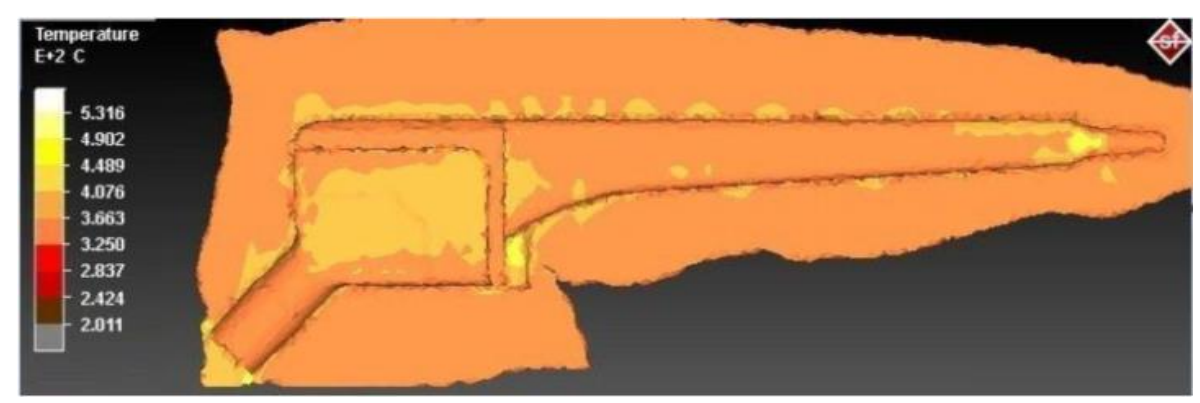

Fig. 10. Temperature distribution in the work-piece.

Regression analysis of pressing velocity, temperature and friction coefficient on temperature showed that there were significant effects on dependent variable (Table 5). Pressing velocity and temperature had a positive effect on stress respectively. Due to nonsignificant effect of friction coefficient, it has been removed from regression model by step-wise procedure. Adjusted R square of the regression analysis showed a high justification of the model $\left(\bar{R}^{2}=0.984\right)$. The results achieved by this analysis confirmed as discussed above.

Table 5. Regression analysis of pressing velocity, temperature and friction coefficient on temperature

\begin{tabular}{|c|c|c|c|c|c|}
\hline \multirow{2}{*}{ Model } & \multicolumn{2}{|c|}{$\begin{array}{c}\text { Unstandardized } \\
\text { Coefficients }\end{array}$} & $\begin{array}{c}\text { Standardized } \\
\text { Coefficients }\end{array}$ & \multirow{2}{*}{$\mathrm{t}$} & Sig. \\
\cline { 2 - 6 } & $\mathrm{B}$ & $\begin{array}{c}\text { Std. } \\
\text { Error }\end{array}$ & Beta & & \\
\hline Temperature & 152.145 & 8.446 & .763 & 18.015 & .000 \\
\hline $\begin{array}{c}\text { Pressing } \\
\text { Velocity }\end{array}$ & 77.406 & 5.172 & .634 & 14.967 & .000 \\
\hline
\end{tabular}

EÜFBED - Fen Bilimleri Enstitüsü Dergisi Cilt-Sayı: 8-1 Yıl: 2015 69-87 
Analysis of Hip Prosthesis Production with Forging Using

Study of die wear values shows that increasing friction coefficient, punch rate and stroke increased the die wear values. Furthermore, decreasing forging temperature also increased the die wear.

Regression analysis of pressing velocity, temperature and friction coefficient on die wear showed that there were significant effects on dependent variable (Table 6). Pressing velocity had a positive effect on die wear, while temperature had a negative effect. Due to non-significant effect of friction coefficient, it has been removed from regression model by step-wise procedure. Adjusted $\mathrm{R}$ square of the regression analysis showed a high justification of the model $\left(\bar{R}^{2}=0.809\right)$. The results achieved by this analysis confirmed as discussed above.

Table 6. Regression analysis of pressing velocity, temperature and friction coefficient on die wear

\begin{tabular}{|c|c|c|c|c|c|}
\hline \multirow{2}{*}{ Model } & \multicolumn{2}{|c|}{$\begin{array}{c}\text { Unstandardized } \\
\text { Coefficients }\end{array}$} & $\begin{array}{c}\text { Standardized } \\
\text { Coefficients }\end{array}$ & \multirow{2}{*}{ Sig. } \\
\cline { 2 - 5 } & B & $\begin{array}{c}\text { Std. } \\
\text { Error }\end{array}$ & Beta & \\
\hline $\begin{array}{c}\text { Pressing Velocity } \\
\text { e }\end{array}$ & 0.002 & 0.000 & 0.831 & 5.701 & 0.000 \\
\hline \begin{tabular}{c} 
Temperature \\
\cline { 2 - 5 }
\end{tabular} & -0.001 & 0.000 & -0.345 & -2.365 & 0.042 \\
\hline
\end{tabular}

\section{RESULTS and CONCLUSIONS}

In this study, the optimum forging parameters for producing complex geometrical hip prosthesis in forging were examined. The optimum values of the die design and the forging process, obtained 
Hojjat and Diğerleri

using FEM and it is abled modelling of complex geometrical hip prosthesis production process. The following results were obtained in FEM analyses of complex geometrical hip prosthesis production process.

- The most suitable solution for problems in the production process of complex geometrical hip prosthesis is to utilize doublestep forging.

- It was observed that the prepared die and work-piece design have a great effect on the formability of the work-piece.

- Work-piece design is in a way that prevents a folding occurrence and the die design makes optimum material flow in the sharp corners and edges.

- Different punch rates $(2,6,10 \mathrm{~mm} / \mathrm{s})$ were used in analyses and the best result was obtained in $2 \mathrm{~mm} / \mathrm{s}$ punch rate.

- Maximum material flow value for $2 \mathrm{~mm} / \mathrm{s}$ punch rate equals $8 \mathrm{~mm} / \mathrm{s}$ and for $10 \mathrm{~mm} / \mathrm{s}$ punch rate were equal to $38 \mathrm{~mm} / \mathrm{s}$.

- $\quad$ For preventing phase transformation at the Ti6Al4V alloy semi-hot forging was used. The semi-hot forging was carried out at $300^{\circ} \mathrm{C}$ and $500^{\circ} \mathrm{C}$ initially. It was discovered that $500^{\circ} \mathrm{C}$ initial temperature results were better for formability.

- $\quad$ Temperature increased during the forging process at $300^{\circ} \mathrm{C}$ and $500^{\circ} \mathrm{C}$ initial temperatures are $80 \%$ and $40 \%$ respectively.

- $\quad$ It was observed that applied $Z^{\prime}$ force increased by increasing punch rate. FEM analyses result 6350 and $5642 \mathrm{kN}$ punch forces for $300^{\circ} \mathrm{C}$ and $500^{\circ} \mathrm{C}$.

EÜFBED - Fen Bilimleri Enstitüsü Dergisi Cilt-Say1: 8-1 Yıl: 2015 69-87 
Analysis of Hip Prosthesis Production with Forging Using - Regression analysis of pressing velocity, temperature and friction coefficient on stress and punch force showed that, pressing velocity and friction coefficient had a positive effect on stress respectively, while temperature had a negative effect.

- Regression analysis of pressing velocity, temperature and friction coefficient on temperature showed that pressing velocity and temperature had a positive effect on stress respectively.

- Regression analysis of pressing velocity, temperature and friction coefficient on die wear showed that pressing velocity had a positive effect on die wear, while temperature had a negative effect.

\section{ACKNOWLEDGMENT}

Hojjat Ghahramanzadeh ASL would like to thank TUBITAK for BIDEB 2215 Scholarship.

\section{REFERENCES}

Behrens, B.A, Schaefer, F, 2005, Prediction of wear in hot forging tools by means of finite-element-analysis, Journal of Materials Processing Technology, 167, 309-315.

Campatelli, G, Scippa, A, 2012, A heuristic approach to meet geometric tolerance in High Pressure Die casting, Simulation Modelling Practice and Theory, 22, 109-122.

Caporalli, A, Gileno, L.A, Button, S.T, 1998, Expert system for hot forging design, Journal of Materials Processing Technology, 80-81,131-135.

Doege, E, Alasti, M, Jürgensen, R.S, 2004, Accurate friction and heat transfer laws for enhanced simulation models of precision

EÜFBED - Fen Bilimleri Enstitüsü Dergisi Cilt-Sayı: 8-1 Yıl: 2015 69-87 
Hojjat and Diğerleri

forging processes, Journal of materials Processing Technology, 150, 92-99.

Feng, J.P, Luo, Z.J, 2000, A method for the optimal control of forging process variables using the finite element method and control theory, Journal of Materials Processing Technology, $108,40-44$.

Garat, V, Bernhar, G, Hervy, L, 2004 Influence of design and process parameters on service life of nut hot forging die, Journal of Materials Processing Technology, 147,359-369.

Hallstrom, J, 2000, Influence of friction on die filling in counterblow hammer forging, Journal of Materials Processing Technology, 108, 21-25.

Hu, Z.M, Brooks, J.W, Dean, T.A, 1999, Experimental and theoretical analysis of deformation and microstructural evolution in the hot-die forging of titanium alloy aerofoil sections, Journal of Materials Processing Technology, 88, 251-265.

$\mathrm{Hu}, \mathrm{Z} . \mathrm{M}$, Dean, T.A, 2001, Aspects of forging of titanium alloys and the production of blade forms, Journal of Materials Processing Technology, 111, 10-19.

Huang, Z.H, 2005, Workability and microstructure evolution of Ti$47 \mathrm{Al}-2 \mathrm{Cr}-1 \mathrm{Nb}$ alloy during isothermal deformation, Intermetallics, 13, 245-250.

Kim, D.H, Lee, H.C, Kim, B.M, Kim, K.H, 2005, Estimation of die service life against plastic deformation and wear during hot forging processes, Journal of Materials Processing Technology, 166, 372-380.

EÜFBED - Fen Bilimleri Enstitüsü Dergisi Cilt-Sayı: 8-1 Yıl: 2015 69-87 
Analysis of Hip Prosthesis Production with Forging Using Lee, R.S, Lin, H.C, 1998, Process design based on the deformation mechanism for the non-isothermal forging of Ti-6Al-4V alloy, Journal of Materials Processing Technology, 79, 224235.

Ou, H, Balendra, R, 1998, Die-elasticity for precision forging of aerofoil sectionsusing finite element method, Journal of Materials Processing Technology, 76, 56-61.

Özkor, M, 2011, SIMUFACT presentation, http://www.ex-en.com.tr.

Saiki, H, Zhan, Z.H, Marumo, Y, Ruan, L, Morooka, T, Tatsuda, S.I, 2006, Evaluation of contact conditions in hot forging of pure aluminum using ltrasonic examination, Journal of Materials Processing Technology, 177, 243-246.

Skubisz, P, Sinczak, J, Bednarek, S, 2006, Forgeability of Mg-Al-Zn magnesium alloys in hot and warm closed die forging, Journal of Materials Processing Technology, 177, 210-213.

Tetsui, T, Shindo, K, Kaji, S, Kobayashi, S, Takeyama, M, 2005, Fabrication of TiAl component by means of hot forging and machining, Intermetallics, 13, 971-978.

Wilson, W.R.D, Schmid, S.R, Liu, J, 2004, Advanced simulations for hot forging: heat transfer model for use with the finite element method, Journal of Materials Processing Technology, 155-156, 1912-1917.

EÜFBED - Fen Bilimleri Enstitüsü Dergisi Cilt-Sayı: 8-1 Yıl: 2015 69-87 